\title{
HUBUNGAN KONSELING MENYUSUI DENGAN SIKAP IBU DALAM PEMBERIAN ASI EKSKLUSIF DI WILAYAH KERJA PUSKESMAS TAWAELI
}

\author{
Sri Restu Tempali ${ }^{1 \mathrm{~K}}$, Rafika $^{2}$, Muliani $^{3}$, Henrietta Imelda Tondong ${ }^{4}$ \\ ${ }^{1}$ '2Prodi DIII Kebidanan, Jurusan Kebidanan, Poltekkes Kemenkes Palu \\ ${ }^{3,4}$ Prodi D.IV Kebidanan Jurusan Kebidanan Poltekkes Kemenkes Palu \\ email Penulis Korespondensi $\left({ }^{\mathrm{K}}\right)$ : restutempali@gmail.com
}

\begin{abstract}
Exclusive breastfeeding is the most appropriate food for babies aged 0-6 months for brain development and infant intelligence as well as to improve the baby's immune system or immunity from disease attacks. The coverage of exclusive breastfeeding is influenced by many factors, one of which is the very limited number of ASI counselors. The purpose of this study is to know the relationship of breastfeeding counseling with mother's attitude in exclusive breastfeeding in Tawaeli Health Center work area. This research includes descriptive correlation type with cross sectional approach. The design of this study was used to analyze the correlative relationship between breastfeeding counseling and the mother's attitude in exclusive breastfeeding. The location of this research is the work area of Puskesmas Taweli in Palu City and implemented on July to August 2015. The sample of this research is all mothers who have babies aged 0-6 months in work area of Puskesmas Taweli in Palu City. Sampling was done by using consecutive sampling, with total sample of 73 people. The results showed no significant relationship between breastfeeding counseling and mother's attitude in exclusive breastfeeding in Tawaeli Health Center Working Area. This can be proved by statistical analysis with $\mathrm{X}^{2}$ value $<\mathrm{X}^{2}$ table $(0,292<92,808)$ at $95 \% \mathrm{CI}$ and $\rho$-value $=0,589>\alpha$ $(0,05)$. Based on the result of the research, it can be concluded that there is no relationship of breastfeeding counseling with mother attitude about exclusive breast feeding in Tawaeli Public Health Working Area.

Keywords: 0-6 months old baby, Mother's attitude, Counseling
\end{abstract}

\section{PENDAHULUAN}

\section{Latar Belakang}

Mempersiapkan generasi penerus yang sehat, cerdas, dan berkualitas harus dilakukan sejak dari dalam kandungan sampai bayi lahir, dimana faktor nutrisi memegang peran penting dalam tahap tumbuh kembang seorang anak. Pemberian Air Susu Ibu (ASI) saja selama 6 bulan pertama dapat memberikan nutrisi terbaik bagi bayi ${ }^{(1)}$.

Salah satu faktor yang mempengaruhi pemberian ASI adalah faktor kurangnya petugas kesehatan yang memberikan penerangan dan motivasi kepada masyarakat khususnya ibu tentang pemberian ASI (2). Akibatnya banyak ibu tidak mendapatkan informasi yang jelas tentang manfaat pemberian ASI. Menurut Chin et al ${ }^{(3)}$., kurangnya pengetahuan dan motivasi menyebabkan ibu gagal dalam praktik menyusui eksklusif.

Kurangnya informasi tentang manfaat pemberian ASI akan berkaitan dengan pengetahuan ibu, dan pada akhirnya akan membentuk sikap ibu terhadap menyusui eksklusif, 
pengetahuan merupakan domain yang sangat penting untuk membentuk sikap seseorang. Sikap adalah respon atau reaksi seseorang yang masih tertutup, terhadap suatu stimulus atau objek ${ }^{(4)}$.

Cakupan ASI eksklusif untuk Provinsi Sulawesi Tengah berdasarkan data Riskesdas tahun 2013 adalah 66,52\%. Data Dinas Kesehatan Kota Palu, cakupan ASI eksklusif Kota Palu 52,03\%. Meskipun data cakupan ASI eksklusif Provinsi Sulawesi Tengah dan Kota Palu sudah cukup baik, namun berdasarkan laporan tahunan Dinas Kesehatan Kota Palu masih ada beberapa Puskesmas dengan angka cakupan ASI eksklusif yang masih sangat rendah termasuk Puskesmas Tawaeli dengan angka cakupan 29,49\%. Dengan penelitian ini dapat diketahui hubungan konseling menyusui dengan sikap ibu dalam pemberian ASI eksklusifdi wilayah kerja Puskesmas Tawaeli.

\section{Tujuan}

Tujuan penelitian untuk mengetahui hubungan konseling menyusui dengan sikap ibu dalam pemberian ASI ekslusif di wilayah kerja Puskesmas Tawaeli. .

\section{METODE PENELITIAN}

Penelitian ini merupakan descriptive correlation dengan pendekatan cross sectional. Desain penelitian ini digunakan untuk menganalisis hubungan korelatif antara konseling menyusui dengan sikap ibu dalam menyusui eksklusif. Penelitian ini dilaksanakan pada bulan Juli-gustus 2015 di wilayah kerja Puskesmas Taweli di Kota Palu. Populasi dalam penelitian ini adalah seluruh ibu yang mempunyai bayi usia 0-6 bulan di wilayah kerja Puskesmas Taweli di Kota Palu yang belum diketahui populasinya. Sampel dalam penelitian ini adalah semua ibu yang mempunyai bayi usia 0-6 bulan di wilayah kerja Puskesmas Taweli di Kota Palu berjumlah 73 orang. Pengambilan sampel dilakukan dengan menggunakan consecutive sampling, pengambilan sampel dilakukan dengan memilih sampel yang memenuhi kriteria penelitiani. Adapun kriteria inklusi penelitian ini meliputi:

a. Ibu yang mempunyai bayi usia 0-6 bulan.

b. Ibu yang telah mendapatkan konseling menyusui eksklusif

c. Bayi yang mendapatkan ASI.

d. Bersedia mengikuti penelitian ini

Teknik pengumpulan data dilakukan dengan membagikan lembar kuesioner kepada ibu hamil, setelah itu responden mengisi kuesioner sampai selesai dan kuesioner dikumpulkan kembali oleh peneliti. Pengolahan data dari karakteristik ibu dan kadar Hb bayi, data yang telah dikumpulkan dilakukan proses Editing, Codding, Skoring, Entry, Tabulating. Data dalam penelitian ini dianalisis dengan menggunakan analisis univariat yaitu analisis menggunakan distribusi frekuensi. Analisis bivariat menggunakan Chi Square untuk menguji hipotesis melihat hubungan konseling menyusui dengan sikap ibu menyusui eksklusif, menggunakan sistem komputerisasi pada tingkat kepercayaan 95\% $(\alpha=0,05)$.

\section{HASIL PENELITIAN}

\section{Analisis Univariat}

Berdasarkan analisis univariat dari hasil penelitian dengan variabel konseling ASI dan sikap ibu menyusui eksklusif dapat dilihat pada tabel berikut: 
Tabel 1

Distribusi Frekuensi Konseling ASI dan sikap ibu Menyusui Eksklusif Di Wilayah Kerja Puskesmas Tawaeli Tahun 2015

\begin{tabular}{lcc}
\hline \multicolumn{1}{c}{ Variabel } & $\mathrm{f}$ & $\%$ \\
\hline Konseling ASI & & \\
Ya & 33 & 45,2 \\
$\quad$ Tidak & 40 & 54,8 \\
Sikap ibu Menyusui & & \\
Baik & 51 & 69,9 \\
$\quad$ Kurang Baik & 22 & 30,1 \\
\hline Total & 73 & 100 \\
\hline
\end{tabular}

Tabel 1 menunjukkan bahwa dari $73 \mathrm{ibu}$ yang tidak mendapatkan konseling ASI sebesar $(45,2 \%)$ dan sebagian ibu mendapatkan konseling ASI sebanyak (54,8\%). Demikian pula sikap ibu menunjukkan dari 73 ibu terdapat sebagian besar $(69,9 \%)$ ibu memiliki sikap baik, sedangkan ibu yang memiliki sikap kurang baik $(30,1 \%)$.

\section{Analisis Bivariat}

Dalam penelitian ini analisis bivariat dilakukan untuk melihat adanya hubungan antar variabel konseling ASI terhadap sikap ibu menyusui eklusif seperti pada Tabel berikut ini.

Tabel 2

Hubungan konseling menyusui dengan sikap ibu tentang pemberian ASI eksklusif di wilayah kerja PKM Tawaeli, 2015

\begin{tabular}{|c|c|c|c|c|c|c|c|}
\hline \multirow{3}{*}{$\begin{array}{c}\text { Konseling } \\
\text { ASI }\end{array}$} & \multicolumn{4}{|c|}{ Sikap Ibu Menyusui } & \multirow{3}{*}{$\mathrm{n}$} & \multirow{3}{*}{$\mathrm{X}_{\mathrm{h}}^{2}$} & \multirow{3}{*}{$\rho$-value } \\
\hline & \multirow{2}{*}{$\frac{\text { Kurang }}{\mathrm{f}}$} & \multirow{2}{*}{$\begin{array}{c}\text { Setuju } \\
\%\end{array}$} & \multicolumn{2}{|c|}{ Setuju } & & & \\
\hline & & & $\mathrm{f}$ & $\%$ & & & \\
\hline Tidak & 11 & 33,3 & 22 & 66,7 & 33 & בר? & 0580 \\
\hline $\mathrm{Ya}$ & 11 & 27,5 & 29 & 72,5 & 40 & 0,292 & 0,589 \\
\hline Total & 22 & 30,1 & 51 & 69,9 & 73 & & \\
\hline
\end{tabular}

Hasil penelitian pada Tabel 2. bahwa ibu yang tidak mendapatkan konseling ASI sebesar 33 orang, diantaranya terdapat 11 orang $(33,3 \%)$ yang memiliki sikap baik dan 22 orang $(66,7 \%)$ sikap kurang baik ibu menyusui. Sedangkan pada 40 ibu yang mendapatkan konseling ASI diantaranya mempunyai sikap baik sebesar 29 orang $(742,5 \%)$ dan 11 orang $(27,5 \%)$ sikap kurang ibu dalam menyusui. Hasil uji statistik menunjukkan tidak ada hubungan yang bermakna ( $\rho$-value 0,589$)$ konseling ASI terhadap sikap ibu menyusui eksklusif di Wiayah Kerja Puskesmas Tawaeli.

\section{PEMBAHASAN}

Hasil analisis univariat pada penelitian ini menunjukkan bahwa konseling ASI tidak mengalami perbedaan antara ibu yang mendapatkan konseling ASI dan yang tidak. Hal ini diketahui masih kurangnya promosi kesehatan dengan metode konseling yang diberikan kepa da mereka. Sehingga diperlukan peran petugas kesehatan dalam hal ini bidan atau 
konselor ASI kepada ibu-ibu bayi untuk melakukan promosi kesehatan dengan konseling, sehingga akan mendorong keberhasilan pemberian ASI eksklusif. Karena dengan adanya konseling yang diberikan kepada ibu dapat terjadi perubahan pengetahuan mereka dengan adanya paparan informasi yang telah diperoleh. Hal ini sesuai dengan pendapat Notoatmodjo tahun 2017 (4) mengatakan bahwa pengetahuan dapat diperoleh dari guru, pengalaman dan media massa lain.

Begitu pula dengan hasil sikap ibu menyusui didapatkan sikap baik yang lebih banyak dibandingkan sikap kurang baik ibu menyusui. Hal ini dimungkinkan pengetahuan mereka dalam menjawab kuisioner cukup baik, sehingga ibu memiliki kesadaran dan motivasi untuk mau menyusui dengan pemberian ASI eksklusif kepada bayinya. Sikap bukan dibawa sejak lahir melainkan dibentuk dan dipelajari sepanjang perkembangan orang tersebut dalam hubungan dengan objeknya ${ }^{(4)}$.

Berdasarkan hasil uji statistik diperoleh $p$ value $=0,589(>0,05)$ artinya tidak ada hubungan yang bermakna antara konseling ASI terhadap sikap ibu menyusui eksklusif, demikian halnya dengan nilai $X^{2}{ }_{\text {hitung }}<X^{2}$ tabel $(0,292<92,808)$ Hal ini karena kurangnya konseling ASI yang didapatkan ibu pada saat mereka kunjungan ke pusat pelayanan kesehatan, sehingga perubahan sikap ibu tidak mengalami perubahan. Dalam hal ini juga bahwa menyusui merupakan perilaku yang bersifat naluri keibuan untuk menyusui bayinya, tetapi sikap ingin menyusui secara eksklusif akan berubah ketika ibu menghadapi masalah menyusi seperti ASI belum keluar, ASI sedikit, bentuk puting, puting lecet, anak rewel dan kurangnya dukungan dari suami, keluarga, petugas kesehatan.

Selain itu pula peran aktif para bidan sebagai konselor yang tidak berjalan dengan efektif di wilayah tersebut, sehingga pengetahuan akan informasi pemberian ASI eksklusif tidak mempengaruhi sikap ibu menyusui. Dapat pula dikarenakan kurangnya keterampilan bidan dalam mengajukan pertanyaan terbuka, merespon perasaan ibu pada saat permasalahan disampiakan, nada bicara yang cenderung menyalahkan ibu serta kurang sabar diduga menjadi faktor kegagalan komunikasi dua arah.

Faktor lain yang membentuk sikap ibu adalah pengetahuan dan praktik pemberian ASI eksklusif yang ada di masyarakat yang sebagian besar tidak eksklusif. Kondisi tersebut akan mempengaruhi motivasi dan emosi ibu yang pada akhirnya akan memberikan penilaian yang relatif tetap baik ${ }^{(5)}$.

Sikap seseorang tidak selamanya konsisten, karena pengaruh sikap dan perlaku akan berkembang dipengaruhi oleh kekuatan sikap, stabilitas sikap, relevansi sikap terhadap perilaku dan tekanan situasi ${ }^{(2)}$.

Menurut pendapat Gunarsa ${ }^{(6)}$, konseling membantu ibu untuk memperoleh bukan saja kemampuan, minat dan kesempatan melainkan juga emosi dan sikap yang bisa mempengaruhi dalam menentukan pilihan dan pengambilan keputusan. Adanya perhatian dan pemberian motivasi dalam bentuk kunjungan rumah setelah melahirkan oleh konselor terhadap ibu menjadi dukungan dalam pemberian ASI eksklusif. Kunjungan rumah, kelompok pertemuan, sesi monitoring pertumbuhan dan sesi memasak merupakan peluang yang baik untuk berbagi informasi dan untuk konseling individu ${ }^{(5)}$.

Hasil penelitian ini pula tidak sejalan dengan penelitian Zainal, dkk. Tahun 2014 (7) menunjukkan bahwa terdapat korelasi yang bermakna antara pengetahuan $(p<0,05)$, sikap $(p<0,05)$, IMD $(p<0,05)$ dan peran bidan $(P<0,05)$ dengan pemberian ASI eksklusif). Faktor yang mempengaruhi peran bidan dalam pelaksanaan IMD dan ASI eksklusif adalah motivasi yang kurang karena beban kerja yang berat, waktu terbatas, pemahaman tugas dan kesadaran yang kurang. Selain itu saranan prasanana dan promosi susu formula juga ikut mempengaruhi.

Hasil penelitian ini berbeda dengan hasil penelitian Gusti tahun $2010^{(8)}$ mengatakan terbentuknya sikap yang positif terhadap pemberian ASI eksklusif setelah memperoleh 
konseling dan penyuluhan. Terjadinya peningkatan pengetahuan dan sikap responden setelah diberikan konseling ASI. Selisih rata-rata pengetahuan dan sikap lebih tinggi kelompok konseling dari kelompok penyuluhan. Pelaksanaan konseling seorang konselor haus memiliki persyaratan keterampilan salah satunya yaitu empati dan menggali lebih lanjut sesuai dengan kebutuhan yang ditolong. Namun bukan berarti dalam melakukan promosi ASI eksklusif dengan metode penyuluhan peneliti tidak menunjukkan sikap yang serius untuk mendapatkan hasil yang maksimal ${ }^{(9)}$.

Dari hasil penelitian menurut Ambarwati, dkk. ${ }^{(5)}$ mengatakan ada perubahan sikap ibu yang mendapat konseling laktasi intensif dibanding ibu yang mendapat konseling laktasi yang diberikan oleh bidan di Puskesmas dan BPS.

\section{SIMPULAN DAN SARAN}

Simpulan penelitian ini bahwa tidak ada hubungan konseling menyusui dengan sikap ibu tentang pemberian ASI eksklusif di Wilayah Kerja Puskesmas Tawaeli. Saran diharapkan pada pihak Puskesmas khususnya bidan di wilayah Puskesmas Tawaeli untuk lebih proaktif melakukan promosi kesehatan metode konseling dengan penyuluhan sehingga memberikan informasi kepada ibu menyusui eksklusif.

\section{DAFTAR PUSTAKA}

1. Sears, F. P. (1992). Psikologi Sosial. Jakarta: Erlangga.

2. Siregar A. (2004). Pemberian Asi Ekslusif dan Faktor-faktor yang Mempengaruhinya.

3. Chin, C.A., L. Myers, JH. Magnus, (2008). Race, Education, and Breastfeeding Initiation in Lousiana 2000-2004. Journal of Human Lactation. 24: 175-18.

4. Notoatmodjo. (2007). Ilmu Perilaku Kesehatan. Jakarta: Renika Cipta.

5. Ambarwati, R., Fatimah MS., Susantini, P. (2013). Pengaruh Konseling Laktasi Intensif terhadap pemberian air susu ibu (ASI) ekslusif sampai 3 bulan. Bagian Ilmu Gizi. Semarang: FK UNDIP.

6. Gunarsa, SD. (2009). Konseling dan Terapi. Jakarta: PT NPK, Gunung Mulia.

7. Zainal, E. Sutedja, E., Husnitawati Madjid T. (2014). Hubungan Antara Pengetahuan Ibu, Sikap Ibu, IMD dan Peran Bidan Dengan Pelaksanaan ASI Ekslusif Serta FaktorFaktor Yang Mempengaruhi Peran Bidan Pada IMD Dan ASI Ekslusif. Pascasarjana UNPAD.

8. Gusti, D. 2010. Promosi ASI Ekslusif Memakai Metode Konseling Dengan Penyuluhan Terhadap Pengetahuan Dan Sikap Pada Ibu Menyusui. Pandang: Akademi Keperawatan Baiturahman. Bagian Ilmu Kesehatan Masyarakat Fakultas Kedokteran Universitas Andalas.

9. Depkes RI. (2007). Pelatihan Konseling Menyusui. Jakarta: Direktorat Bina Gizi Masyarakat. 